\title{
Neurological manifestation of sacral tumors
}

\author{
Michael Payer, M.D. \\ Department of Neurosurgery, University Hopital of Geneva, Switzerland
}

\begin{abstract}
An extensive analysis of the existing literature concerning sacral tumors was conducted to characterize their clinical manifestations. Although certain specific manifestations can be attributed to some of the tumor types, a more general pattern of clinical presentation of an expansive sacral lesion can be elaborated. Local pain with or without pseudoradicular or radicular radiation is the most frequent initial symptom and is usually followed by the manifestation of a lumbosacral sensorimotor deficit; bladder/bowel and/or sexual dysfunction appear throughout the natural course of disease.
\end{abstract}

KEY WORDS • sacrum • tumor • lesion • neurological presentation

All sacral and presacral tumors are rare..$^{32,93}$ In one series patients with these tumors were estimated to account for approximately one in 40,000 hospital admissions. ${ }^{93}$ Tumors arising from the bone of the sacrum are by far the most frequent sacral tumors; chordomas are the most common and GCTs the second most common. . $^{20,46,50,61,74,81,98}$ Although sacrococcygeal teratoma is the most common sacral tumor in neonates, it is very rare in adults. ${ }^{30,45,66}$

The author conducted an extensive analysis of the existing literature concerning tumors of the sacrum to characterize their clinical manifestations. It was found that an expansive space-occupying lesion of the sacrum usually leads to a specific pattern of clinical signs and symptoms throughout its natural history. This clinical pattern depends on the anatomical location of the lesion within the sacrum, its extension, and whether it compresses or invades neighboring structures. Because the histological type of the lesion plays only a minor role in this context, it is usually difficult or impossible to determine a sacral tumor type based on its clinical presentation alone. Its precise location, the patient's age at symptom onset, external appearance, and accompanying the patient's general symptoms, however, can characterize some sacral tumors.

Because the clinical presentation of a sacral tumor depends largely on the structures it erodes or compresses, a short overview of the clinically relevant anatomy of the sacrum and its surrounding structures is given.

Abbreviations used in this paper: GCT = giant cell tumor; $\mathrm{PNET}=$ primitive neuroectodermal tumor.

\section{REVIEW OF SACRAL ANATOMY}

\section{Osseous Structures of the Sacrum}

The sacrum is a complex bone, comprising five sacral vertebrae that have fused. In its center lies the longitudinal sacral canal, which opens caudally posteriorly into the sacral hiatus, an incomplete posterior closure of the S-5 lamina. The thick anterior or pelvic face of the sacrum is concave and contains four right- and left-sided anterior sacral foramina. The posterior face of the sacrum is convex, thin, and has four right- and left-sided posterior sacral foramina. The S1-4 spinous processes have merged to form a median sacral crest, caudal to which lies the sacral hiatus at S-5. The superior face of the sacrum consists of an upper endplate, bearing the L5-S1 disc, a wide ala to the right and left, and the horizontally positioned superior articular process. ${ }^{11,48}$

\section{Joints of the Sacrum}

The L5-S1 joint articulates through a disc medially and two facet articulations on each side, allowing for a maximum of 10 to $15^{\circ}$ of combined flexion-extension and $5^{\circ}$ of rotation on either side. The sacroiliac joints and sacrococcygeal joints are amphiarthroses and have no measurable mobility. ${ }^{11,94}$

\section{Ligaments of the Sacrum}

The sacrotuberous and -spinous ligaments connect the sacrum to the ischial tuberosity and ischial spine, respectively, and resist backward rotation of the lower sacrum. 
The dorsal sacroiliac ligament spanning the sacroiliac joint and the interosseous sacroiliac ligaments within the sacroiliac joint restrain forward rotation of the upper sacrum. There is also a weak anterior sacroiliac ligament. ${ }^{94}$

\section{Neurological Structures at the Sacrum}

The dural sac converges within the sacral canal in a craniocaudal direction and ends blindly at the level of S-2. The terminal filum, a prolongation of the pia, extends from the conus medullaris down to the end ot the dural sac, where it fuses with the dura mater. It then continues further caudally and attaches to the periosteum of the first coccygeal segment. The L-5 nerve roots exit the spinal canal through the L5-S1 foramen, passing through a small groove at the anterior surface of the sacral alae. The S1-4 nerve roots exit with their ventral rami through the anterior sacral foramina, with their dorsal rami through the posterior sacral foramina. The S-5 roots exit at the caudal margin of the sacrum. The L-5 roots more laterally connect with the L-4 roots and then with the S1-3 and part of S-4 roots to form the lumbosacral plexus on each side.

The superior hypogastric plexus lies around the aortic bifurcation and anterior surface of the L-5 vertebra and the upper sacrum, and it connects to the inferior hypogastric plexus, which surrounds the different pelvic viscera.

The caudal most portions of the paired sympathetic trunks lie on the pelvic surface of the sacrum, containing four or five ganglia each, and terminate by uniting in the midline to the ganglion impar anterior to the coccyx..$^{11,18,48,92}$

\section{Neighboring Structures at the Sacrum}

Anterior to the sacrum lies the presacral or retrorectal space, bounded by the rectum anteriorly, the sacrum posteriorly, the peritoneal reflection superiorly at the S2-3 junction, the levator ani and coccygeal muscle inferiorly, and the ureters and iliac vessels laterally.

The median sacral artery and vein from the aortic bifurcation, and to the iliac bifurcation respectively, overlie the sacrum in the midline down to the coccyx. Lateral sacral arteries arise from the internal iliac artery on each side and travel through the anterior sacral foramina, sometimes exiting through the posterior sacral foramina.

On the posterior surface of the sacrum, the erector spinae and multifidus muscles originate, and the pyriform muscle and gluteus maximus muscle originate at the lateral margin of the sacrum. ${ }^{11,76}$

\section{CLINICAL MATERIAL AND METHODS}

The readily available English-language literature on sacral tumors was studied to determine the clinical manifestations of this lesion. Because the sacrum can harbor a variety of nonneoplastic tumors in the sense of spaceoccupying lesions, they were included in the analysis.

\section{RESULTS}

\section{General Clinical Manifestations}

The most common initial symptom of a sacral tumor is local pain due to its mass effect. ${ }^{35,67}$ As nerve roots be- come increasingly compressed or even infiltrated by tumor, radicular pain also develops, radiating uni- or bilaterally into buttocks, posterior thigh or leg, external genitalia, and perineum. ${ }^{35,67}$ This radiating sacral pain is often exacerbated by Valsalva maneuvers ${ }^{96}$ and predominates at night. ${ }^{67}$ The natural neurological history of an expanding sacral lesion will then be characterized by a single- but usually multiradicular sensory deficit and, at a later stage, motor deficit; ${ }^{67}$ eventually, bladder/bowel and/or sexual dysfunction is noted ${ }^{67}$ These latter autonomic dysfunctions may evolve together or separately in any possible order and combination. ${ }^{96}$ Involvement of lumbosacral nerve roots in sacral lesions leads to certain specific deficits. ${ }^{35,67,96}$ A lesion involving the L-5 nerve root, commonly in its L5-S1 foraminal or extraforaminal course, may cause radicular pain and hypesthesias in the lateral thigh and calf as well as dorsum of the foot to the great toe. Motor weakness of the L-5 nerve root may result in weakened ankle dorsiflexion, great toe extension, knee flexion, and hip abduction. The straight-leg raise test is positive. A lesion involving the S-1 nerve root, in its canalicular, S1-2 foraminal or extraforaminal course, typically causes radicular pain and hypesthesias in the posterior thigh and calf as well as at the lateral and plantar face of the foot and the small toe. A motor deficit due to an S-1 lesion may result in weakened ankle plantar flexion, knee flexion, and hip extension. The straight-leg raise test is positive.

A canalicular, foraminal, or extraforaminal lesion of the S-2 nerve root can cause pain and hypesthesia in the posterior thigh or leg, the testicles or labia, and slight weakness of the ankle plantar flexion. Pain and hypesthesia in the outer perianal region and the penis or labia is typical of an S-3 nerve root lesion; inner perianal pain and hypesthesia are associated with an S-4 or S-5 root lesion. A unilateral lesion to the S-2 or S-3 nerve root usually leads to mild or moderate bladder, bowel, and/or sexual dysfunction, although in the case previously mentioned unilateral resection of the S2-4 roots did not result in bladder or bowel dysfunction. ${ }^{6}$ A bilateral lesion of the S-2 or S-3 roots always results in complete bladder, bowel, and sexual dysfunction. ${ }^{13,20}$ Unilateral or even bilateral lesions of the S-4 and/or S-5 roots do not result in autonomic dysfunction, ${ }^{13,20}$ even though anatomical work has shown some S-4 and S-5 root contribution to bladder and bowel function. ${ }^{96}$ In other words, and this has been shown experimentally by Gunterberg and colleagues ${ }^{40-42}$ bilateral preservation of the S-2 and S-3 roots is required for intact autonomic bladder and bowel function.

Several reflex changes can be observed in sacral tumors at neurological examination. An absent ankle jerk reflex is the most common, resulting from an afferent or efferent S-1 nerve root dysfunction. 5,67 An absent plantar reflex stems from an afferent S-1 or efferent S-1 or S-2 root lesion. ${ }^{18}$ The absence of the bulbocavernosus reflex in men or the sphincter vaginae reflex in women usually reflects an afferent or efferent S-3 or S-4 root lesion. ${ }^{18}$ An absent anal reflex is attributed to an afferent or efferent S-4, S-5 or coccyx root lesion. ${ }^{18}$

There are a number of nonneurological clinical manifestations of sacral tumors that arise when the lesions invade neighboring structures. Lateral extension of sacral 
tumors across the sacroiliac joints cause local pain at the joint, which is exacerbated when upright and walking. ${ }^{56,81}$ Anterior extension of the tumor into the presacral space can compress the rectum impeding bowel movements, bladder emptying, and uterine function, causing dystocia: $19,20,58,100,101$ however, no tumor has ever been observed to cross the presacral fascia and invade the rectum. ${ }^{19,20,100}$ Invasion of the origin of the gluteus maximus and pyriforme muscles leads to local pain and subsequently decreases hip extension and external rotation power. ${ }^{100}$

\section{Specific Manifestations of Various Sacral Tumors}

Chordoma. Chordoma is the most common neoplasm of the sacrum..$^{20,46,50,74,81,98}$ It is a usually malignant, slow growing, locally aggressive tumor that originates from remnants of the notocord, and approximately $50 \%$ of all chordomas are located in the sacrum, $35 \%$ at the skull base, and $15 \%$ in the mobile spine. ${ }^{13,19,100,101}$ The mean age of patients at diagnosis is 40 to 70 years. ${ }^{13,100,101}$ Almost all patients suffer local pain, which is sharp or dull, continuous and frequently located in the rectum. ${ }^{38,52,82}$ Approximately $50 \%$ of patients experience additional sacral radicular pain or leg weakness and/or bladder and bowel dysfunction. ${ }^{13,101} \mathrm{~A}$ palpable rectal mass is found in the majority of the patients because the lesion commonly expands into the presacral space. ${ }^{19,101}$ The mean duration of symptoms prior to diagnosis is 2 years. ${ }^{13}$ The rectum is not involved anteriorly through the presacral fascia. ${ }^{19,20,100}$ Infiltration of the gluteal muscles has been observed. ${ }^{100}$

Other Primary Malignant Bone Tumors. Ewing sarcoma, chondrosarcoma, osteosarcoma, myeloma, hemangiopericytoma, and lymphoma of the sacrum have been reported. ${ }^{8,10,27,44,53,55,57,84,99}$ Their clinical presentation is characterized by progressive relentless local pain with radicular lumbosacral radiation, progressive lumbosacral sensorimotor dysfunction, and sphincter dysfunction as well as direct compression of the rectum resulting in constipation..$^{8,10,27,44,53,55,57,84,99}$ Fever and weight loss, typical symptoms of any malignant tumor, may be present. ${ }^{69}$

Giant Cell Tumors. Giant cell tumors are the second most frequent tumor of the sacrum. ${ }^{74,81,98}$ Between 1 and $8 \%$ of GCTs are located in the sacrum, ${ }^{6,58,81,86}$ whereas the majority are found in long bones, typically in the distal femur, proximal tibia and distal radius. ${ }^{81,86}$ Giant cell tumors are commonly benign osteolytic, expansive bone tumors; $6,58,89$ however, local malignant transformation has been observed in up to $16 \%, 6,89$ and both benign and malignant pulmonary metastases have been found in 3 to $12 \%$ of cases. ${ }^{6,81,86,89}$ Most sacral GCTs are found eccentrically in the proximal sacrum, $6,58,81,86,89$ but can be located distally as well as and are usually very large (diameter $5-11 \mathrm{~cm})$ at diagnosis. , $^{61,86}$

Patients with a sacral GCT are usually between the ages of 20 and 40 years when the diagnosis is established. $6,58,81,86,89$ Sacral GCTs manifest initially with local pain over the sacrum or lumbosacral junction that frequently radiate into the posterior aspect of one or both thighs. ${ }^{81,86,89}$ The mean duration of pain until diagnosis has been shown to range from 3 to 8 months. ${ }^{81,86}$ Weeks to months after onset of local pain, symptoms and signs of radicular compression appear, depending on the location and extent of the tumor. ${ }^{6,56,58,81,86,89}$ Because of their local invasiveness, sacral GCTs can cross the sacroiliac joint, ${ }^{56,81}$ causing local joint pain, or the L5-S1 disc space, ${ }^{56,81}$ causing L-5 nerve root compression, and lead to direct compression of the rectum; most patients present with a palpable mass on rectal examination. ${ }^{58}$

Aneurysmal Bone Cysts. Aneurysmal bone cysts are hypervascular lytic lesions with surrounding sclerosis and can be found in the sacrum. ${ }^{17,22,77}$ They usually reach a large size before causing neurological symptoms. ${ }^{34}$ Typical features include a 2-year history of local pain with different lumbosacral nerve root compression symptoms and an age between 10 and 20 years. ${ }^{17,22,77}$

Other Benign Primary Intraosseous Sacral Tumors. Because of their extreme rarity, the clinical pattern of the following benign primary intraosseous sacral tumors has not been established: chondroblastoma, ${ }^{3}$ chondromyxoid fibroma, ${ }^{80}$ osteochondroma, ${ }^{77}$ osteoid osteoma, ${ }^{16}$ osteoblastoma, ${ }^{16}$ Paget disease,${ }^{75}$ fibrous dysplasia, ${ }^{25}$ eosinophilic granuloma, ${ }^{23}$ and hemangioma. ${ }^{69}$

Sacral Ependymoma. Sacral ependymomas arise from ependymal cells of the terminal filum, expand the sacral canal, and are usually of the benign myxopapillary type. ${ }^{31,33,64,67}$ Local pain with or without radicular lumbosacral radiation is the common initial symptom, typically present in men 30 to 40 years of age. ${ }^{31,33,64,67}$ Sensorimotor symptoms and sphincter dysfunction usually follow, resulting in a cauda equina syndrome, and time from initial symptoms to diagnosis is typically 2 to 3 years. ${ }^{31,33,64,67}$

Sacral Schwannoma. Sacral schwannomas or neurofibromas grow within the sacral canal and only rarely expand through the anterior sacral foramina into the presacral space. ${ }^{2,28,67,68,71,87}$ Local pain or radicular lumbosacral radiation is the common initial symptom, typically present in women 30 to 40 years of age. Sacral paresthesias and dysesthesias are very frequent, whereas motor symptoms and sphincter dysfunction are rare. ${ }^{67,68}$ Time from onset of initial symptoms to diagnosis is commonly 5 years. ${ }^{67,68}$

Sacral Meningioma. Sacral meningiomas are even more rare than sacral ependymomas and schwannomas, arise within the sacral canal, and resemble sacral schwannomas in presentation. ${ }^{4,15,29,97}$

Sacrococcygeal Teratoma. Sacrococcygeal teratoma is the most common sacral tumor in neonates, although it is very rare in adults. ${ }^{30,45,66}$ These tumors are composed of multiple tissues foreign to the tissue in which they arise, ${ }^{95}$ and skin, teeth, central nervous system tissue, and respiratory and alimentary mucosa are commonly found in their tissue. ${ }^{24,66,88,91,95}$ They develop during intrauterine growth and prepartum diagnosis can often be made using ultrasonography. ${ }^{21,37,51}$ Sacrococcygeal teratomas can grow so large that their size causes dystocia. ${ }^{24,88,91}$ Postpartum, these tumors can usually easily be diagnosed because of a characteristic exophytic mass between the anus and the coccyx, covered by normal skin. ${ }^{24,88,91}$ Extension into the presacral space can lead to compression of the rectum or bladder. ${ }^{24,66,88,91,95}$ Motor deficits are not present at birth but may develop in childhood because of malignant invasion of the spinal canal. ${ }^{24,88,91}$ Onset of symptoms in adulthood is exceptional but has been reported..$^{30,45,66}$

Presacral Neurogenic Tumors. Neuroblastoma is an in- 
completely differentiated tumor derived from embryonic neural crest tissue and clinically manifests in infancy. ${ }^{26}$ Ganglioneuroma, originated from sympathetic ganglion cells, and neurofibroma, originating from sacral nerve roots, present clinically in young adults. ${ }^{9}$ These tumors typically cause constipation and urinary retention due to direct compression of the rectum and the bladder., ${ }^{9,26}$

Primitive Neuroectodermal Tumors. Usually found intracranially, PNETs are malignant lesions of undifferentiated cells resembling germinal matrix cells of the embryonic neural tube. They can seed through the subarachnoid space into the spinal canal. ${ }^{59}$ One case of a sacral PNET has been reported ${ }^{59}$ which was a primary PNET arising from the right S-1 nerve root, eroding the neural foramen and the sacral canal. Compression of the thecal sac resulted in a progressive $\mathrm{S}-1$ sensorimotor deficit and then bladder and bowel dysfunction.

Carcinoid Tumor. Carcinoid tumor of the sacrum is extremely rare and limited to single case reports. ${ }^{30,76}$ It derives from endocrine gastrointestinal amine precursor uptake and decarboxylation cells, and is typically located in the appendix, ileum, lung, and rectum and can cause socalled "carcinoid syndrome" with flushing, wheezing, watery diarrhea, abdominal pain, heart failure and edema because of its release of serotonin and bradykinin. ${ }^{30,76} \mathrm{~A}$ carcinoid tumor in the sacrum/presacral space can be a metastatic disease or associated with a rest of enteric tissue. ${ }^{30,76}$ Bladder and/or bowel dysfunction has been described as clinical presentation, but not the carcinoid syndrome. $^{76}$

Amyloid of the Sacrum. Amyloid tumors usually occur in the context of multiple myeloma or plasma cell dyscrasia. ${ }^{39}$ One case of a $10-\mathrm{cm}$-diameter primary sacral amyloid has been described. ${ }^{39}$

Sacral Metastases. The clinical presentation of sacral bone metastases cannot be unified and follows the unspecific clinical pattern as mentioned previously. The history of a known primary and general symptoms such as weight loss and fever raise the suspicion of a secondary sacral lesion in this context. ${ }^{43,73}$

Posterior Sacral Meningocele, Myelomeningocele, and Lipomyelomeningocele. Spinal dysraphism is the most common congenital anomaly in neurosurgery. ${ }^{36,63}$ If a myelomeningocele is present, asymmetrical sensory or motor deficits, some form of neurogenic bladder dysfunction, and often hydrocephalus in the context of a Chiari Type II malformation, are found immediately after birth. ${ }^{36,60,62,63} \mathrm{In}$ a lipomyelomeningocele a fatty mass is attached to the conus medullaris or terminale filum. ${ }^{54,78}$ It can manifest at birth as a neurological deficit similar to myelomeningocele; it can also manifest in childhood or young adulthood as progressive lower-extremity sensorimotor and sphincter dysfunction due to growth of the lipoma and progressive mechanical compression, or due to progressive tethering of the spinal cord during axial growth of the spine. ${ }^{12,54,78}$ Lumbosacral cutaneus abnormalities such as a subcutaneous lipoma, hemangioma, hairy patch, dimples, sinus tract, or skin tag are typical, as are orthopedic foot deformities and scoliosis. $12,54,78$

Anterior Sacral Meningocele. An anterior sacral meningocele is a cerebrospinal fluid-filled protrusion of the meninges through a defect in the anterior sacrum. ${ }^{7,47}$ It can cause chronic constipation, urinary obstruction or frequency, and dystocia or dysmenorrhea due to direct mechanical compression of the rectum, bladder, and uterus, respectively. $7,47,85,90$ Neurological symptoms include bladder and anal spincter dysfunction and leg pain and paresthesias caused by compression of the lumbosacral plexus, respectively., $77,85,90$ Shift of cerebrospinal fluid from the anterior sacral meningocele into the spinal dural sac during bowel movements has been associated with headache. ${ }^{47,90}$

Benign Sacral Meningeal Cysts. Benign sacral meningeal cysts are frequent coincidental findings in the radiological examination of the sacrum, and their pathogensis is poorly understood. ${ }^{1,14,49,65,72,79,83} \mathrm{~A}$ familial tendency has been described. ${ }^{1,79}$ In the most common classification they are divided into extradural meningeal cysts without nerve root fibers, extradural meningeal cysts with nerve root fibers, and intradural meningel cysts. ${ }^{65}$ Benign sacral meningeal cysts may cause symptoms typically in the third or fourth decade and manifest as of local pain due to osseous erosion as well as sacral radicular pain and paresthesias, especially in the perineal region. Sphincter dysfunction and sensory loss or motor weakness are very uncommon. . $^{14,49,65,72,79,83}$

\section{CONCLUSIONS}

The most common pattern of neurological manifestation during the natural course of a sacral tumor is initial local pain with or without pseudoradicular or radicular lumbosacral irradiation; this is followed by lumbosacral sensorimotor deficit and finally by bladder and/or bowel and/or sexual dysfunction.

\section{References}

1. Aarabi B, Pasternak G, Hurko O, et al: Familial intradural arachnoid cysts. Report of two cases. J Neurosurg 50: 826-829, 1979

2. Abernathey CD, Onofrio BM, Scheithauer B, et al: Surgical management of giant sacral schwannomas. J Neurosurg 65: 286-295, 1986

3. Akai M, Tateishi A, Machinami R, et al: Chondroblastoma of the sacrum. A case report. Acta Orthop Scand 57:378-381, 1986

4. Alameda F, Lloreta J, Ferrer MD, et al: Clear cell meningioma of the lumbo-sacral spine with choroid features. Ultrastruct Pathol 23:51-58, 1999

5. Allen IM: Tumours involving the cauda equina: A review of their clinical features and differential diagnosis. J Neurol Psychopathol 11:111-143, 1930

6. Althausen PL, Schneider PD, Bold RJ, et al: Multimodality management of a giant cell tumor arising in the proximal sacrum: case report. Spine 27:361-365, 2002

7. Amacher AL, Drake CG, McLachlin AD: Anterior sacral meningocele. Surg Gynecol Obstet 126:986-994, 1968

8. Ampil FL, Mills GM, Burton GV, et al: Solitary plasmacytoma of the sacrum presenting as a pelvic mass: report of two cases. South Med J 88:494- 496, 1995

9. Andersen HJ, Hansen LG, Lange P, et al: Presacral ganglioneuroma. Case report. Acta Chir Scand 152:777-778, 1986

10. Baker ND, Dorfman DM: Ewing's sarcoma of the sacrum. Skeletal Radiol 25:302-304, 1996

11. Basmajian JV: Grant's Method of Anatomy: by Regions, 
Descriptive and Deductive. Baltimore: Williams \& Wilkins, 1980

12. Bassett R: The neurologic deficit associated with lipomas of the cauda equina. Ann Surg 131:109-116, 1950

13. Bergh P, Kindblom LG, Gunterberg B, et al: Prognostic factors in chordoma of the sacrum and mobile spine: a study of 39 patients. Cancer 88:2122-2134, 2000

14. Bergland RM: Congenital intraspinal extradural cyst. Report of three cases in one family. J Neurosurg 28:495-499, 1968

15. Bridges LR, Roche S, Nashef L, et al: Haemangiopericytic meningioma of the sacral canal: a case report. J Neurol Neurosurg Psychiatry 51:288-290, 1988

16. Capanna R, Ayala A, Bertoni F, et al: Sacral osteoid osteoma and osteoblastoma: a report of 13 cases. Arch Orthop Trauma Surg 105:205-210, 1986

17. Capanna R, Van Horn JR, Biagini R, et al: Aneurysmal bone cyst of the sacrum. Skeletal Radiol 18:109-113, 1989

18. Carpenter MB: Human Neuroanatomy. Baltimore: Williams \& Wilkins, 1976

19. Chandawarkar RY: Sacrococcygeal chordoma: review of 50 consecutive patients. World J Surg 20:717-719, 1996

20. Cheng EY, Oezerdemoglu RA, Transfeldt EE, et al: Lumbosacral chordoma. Prognostic factors and treatment. Spine 24: 1639-1645, 1999

21. Chisholm CA, Heider AL, Kuller JA, et al: Prenatal diagnosis and perinatal managment of fetal sacrococcygeal teratoma. Am J Perinatol 16:47-50, 1999

22. Cohen D, Dahlin D, MacCarty C: Vertebral giant-cell tumor and variants. Cancer 17:461-472, 1964

23. Crone-Munzebrock V, Heller M: The roentgenographic, CT, and scintigraphic evaluation of eosinophilic granuloma. Fortschr Rontgenstr 138:633-635, 1983

24. De Backer A, Erpicum P, Philippe P, et al: Sacrococcygeal teratoma: results of a retrospective multicentric study in Belgium and Luxembourg. Eur J Pediatr Surg 11:182-185, 2001

25. Ehara S, Kattapuram SV, Rosenberg AE: Fibrous dysplasia of the spine. Spine 17:977-979, 1992

26. El Shafie M: The many faces of neuroblastoma. A review of the multiple manifestations with emphasis on chronic diarrhea due to VIP secretions. Contemp Surg 24:97-107, 1984

27. Evans RG, Nesbit ME, Gehan EA, et al: Multimodal therapy for the management of localized Ewing's sarcoma of pelvic and sacral bones: a report from the second intergroup study. J Clin Oncol 9:1173-1180, 1991

28. Feldenzer JA, McGauley JL, McGillicuddy JE: Sacral and presacral tumors: problems in diagnosis and management. Neurosurgery 25:884-891, 1989

29. Feldenzer JA, McGillicuddy JE, Hopkins JW: Giant sacral lumbar meningioma. Case report. J Neurosurg 72:951-954, 1990

30. Fiandaca MS, Ross WK, Pearl GS, et al: Carcinoid tumor in a presacral teratoma associated with an anterior sacral meningocele: case report and review of the literature. Neurosurgery 22: 581-588, 1988

31. Fourney DR, Fuller GN, Gokaslan ZL: Intraspinal extradural myxopapillary ependymoma of the sacrum arising from the filum terminale externa. Case report. J Neurosurg 93 (Spine 2):322-326, 2000

32. Freier DT, Stanley JC, Thompson NW: Retrorectal tumors in adults. Surg Gynecol Obstet 132:681-686, 1971

33. Gerston KF, Suprun H, Cohen H, et al: Presacral myxopapillary ependymoma presenting as an abdominal mass in a child. J Pediatr Surg 20:276-278, 1985

34. Goldenberg RR, Campbell CJ, Bonfiglio M: Giant cell tumor of bone. An analysis of two hundred eighteen cases. J Bone Joint Surg Am 52:619-664, 1970

35. Goldner J: Pain: extremities and spine-evaluation and differential diagnosis, in Omer G, Spinner M (eds): Management of Peripheral Nerve Problems. Philadelphia: WB Saunders, 1980, p 169
36. Goumnerova L: Posterior sacral meningoceles and myelomeningoceles, in Doty J, Rengachary S (eds): Surgical Disorders of the Sacrum. Stuttgart: Georg Thieme, 1994, pp 96-101

37. Graf JL, Albanese CT: Fetal sacrococcygeal teratoma. World J Surg 27:84-86, 2003

38. Gray SW, Singhabhandhu B, Smith RA, et al: Sacrococcygeal chordoma: report of a case and review of the literature. Surgery 78:573-582, 1975

39. Griffin M, Parai M, Fernandez D, et al: Amyloid tumor of the sacrum. A case report. Acta Cytol 39:503-506, 1995

40. Gunterberg B: Effects of major resection of the sacrum. Clinical studies on urogenital and anorectal function and a biomechanical study on pelvic strength. Acta Orthop Scand Suppl 162: $1-38,1976$

41. Gunterberg B, Kewenter J, Petersen I, et al: Anorectal function after major resections of the sacrum with bilateral or unilateral sacrifice of sacral nerves. Br J Surg 63:546-554, 1976

42. Gunterberg B, Norlen L, Stener B, et al: Neurologic evaluation after resection of the sacrum. Invest Urol 13:183-188, 1975

43. Hall JH, Fleming JF: The "lumbar disc syndrome" produced by sacral metastases. Can J Surg 13:149-156, 1970

44. Hashimoto M, Akabane Y, Tate E: Ewing's sarcoma of the sacrum. Radiat Med 17:451-453, 1999

45. Head HD, Gerstein JD, Muir RW: Presacral teratoma in the adult. Am Surg 41:240-248, 1975

46. Higinbotham NL, Phillips RF, Farr HW, et al: Chordoma. Thirty-five year study at Memorial Hospital. Cancer 20: 1841-1850, 1967

47. Jabre A, Ball JB Jr, Tew JM Jr: Anterior sacral meningocele. Current diagnosis. Surg Neurol 23:9-13, 1985

48. Jackson H, Burke JT: The sacral foramina. Skeletal Radiol 11:282-288, 1984

49. Janecki CJ, Nelson CL, Dohn DF: Intrasacral cyst. Report of a case and review of the literature. J Bone Joint Surg Am 54: 423-428, 1972

50. Kaiser TE, Pritchard DJ, Unni KK: Clinicopathologic study of sacrococcygeal chordoma. Cancer 53:2574-2578, 1984

51. Kamata S, Imura K, Kubota A, et al: Operative management for sacrococcygeal teratoma diagnosed in utero. J Pediatr Surg 36:545-548, 2001

52. Kamrin R, Potanos J, Pool J: An evaluation of the diagnosis and treatment of chordoma. J Neurol Neurosurg Psychiatry 27: $157-165,1964$

53. Kollender Y, Shabat S, Bickels J, et al: Internal hemipelvectomy for bone sarcomas in children and young adults: surgical considerations. Eur J Surg Oncol 26:398-404, 2000

54. Kuharik MA, Edwards MK, Grossman CB: Magnetic resonance evaluation of pediatric spinal dysraphism. Pediatr Neurosci 12:213-218, 1985

55. Lanzieri CF, Sacher M, Solodnik P, et al: Unusual patterns of solitary sacral plasmacytoma. AJNR 8:566-567, 1987

56. Larsson SE, Lorentzon R, Boquist L: Giant-cell tumors of the spine and sacrum causing neurological symptoms. Clin Orthop 111:201-211, 1975

57. Levine AM, Chretien P: Deep venous occlusion as the initial presentation of osteogenic sarcoma of the sacrum. A case report. J Bone Joint Surg Am 61:775-776, 1979

58. Lin PP, Guzel VB, Moura MF, et al: Long-term follow-up of patients with giant cell tumor of the sacrum treated with selective arterial embolization. Cancer 95:1317-1325, 2002

59. Liu HM, Yang WC, Garcia RL, et al: Intraspinal primitive neuroectodermal tumor arising from the sacral spinal nerve root. J Comput Tomogr 11:350-354, 1987

60. Lorber J: Results of treatment of myelomeningocele. An analysis of 524 unselected cases with special reference to possible selection for treatment. Dev Med Child Neurol 13:279-303, 1971

61. McGillicuddy J, Feldenzer J: Intrasacral meningiomas, in Doty 
J, Rengachary S (eds): Surgical Disorders of the Sacrum. Stuttgart: Georg Thieme, 1994, pp 197-204

62. McLone D, Dices L, Kaplan W, et al: Concepts in the management of spina bifida, in Humphreys R (ed): Concepts in Pediatric Neurosurgery. Basel: S. Karger, 1985, Vol 5

63. Milunsky A, Alper E, Neff RK, et al: Prenatal diagnosis of neural tube defects. IV. Maternal serum alpha-fetoprotein screening. Obstet Gynecol 55:60-66, 1980

64. Miralbell R, Louis DN, O'Keefe D, et al: Metastatic ependymoma of the sacrum. Cancer 65:2353-2355, 1990

65. Nabors MW, Pait TG, Byrd EB, et al: Updated assessment and current classification of spinal meningeal cysts. J Neurosurg 68:366-377, 1988

66. Ng EW, Porcu P, Loehrer PJ Sr: Sacrococcygeal teratoma in adults: case reports and a review of the literature. Cancer 86: 1198-202, 1999

67. Norstrom C, Kernohan J, Love J: One hundred primary caudal tumors. JAMA 178:1071-1077, 1961

68. Piera JB, Durand J, Pannier S, et al: [10 cases of giant lumbosacral neurinoma.] Ann Med Interne 126:316-330, 1975 (Fr)

69. Pitcher J, Springfield D: Benign primary bony lesions of the sacrum, in Doty J, Rengachary S (eds): Surgical Disorders of the Sacrum. Stuttgart: Georg Thieme, 1994, pp 221-227

70. Pitcher J, Springfield D. Malignant primary lesions of the sacrum, in Doty J, Rengachary S (eds): Surgical Disorders of the Sacrum. Stuttgart: Georg Thieme, 1994, pp 230-233

71. Rengachary SS, O'Boynick P, Batnitzky S, et al: Giant intrasacral schwannoma: case report. Neurosurgery 9:573-577, 1981

72. Rengachary SS, O’Boynick P, Karlin CA, et al: Intrasacral extradural communicating arachnoid cyst: case report. Neurosurgery 8:236-240, 1981

73. Salehi SA, McCafferty RR, Karahalios D, et al: Neural function preservation and early mobilization after resection of metastatic sacral tumors and lumbosacropelvic junction reconstruction. Report of three cases. J Neurosurg 97 (Spine 1):88-93, 2002

74. Sar C, Eralp L: Surgical treatment of primary tumors of the sacrum. Arch Orthop Trauma Surg 122(3):148-155, 2002

75. Schajowicz F, Velan O, Santini Araujo E, et al: Metastases of carcinoma in the pagetic bone. A report of two cases. Clin Orthop 288:290-296, 1988

76. Schnee CL, Hurst RW, Curtis MT, et al: Carcinoid tumor of the sacrum: case report. Neurosurgery 35:1163-1167, 1994

77. Schurmann K, Wallenfang T: Rare sacral space-occupying lesions, their surgical management and reconstructive measures involved. Acta Neurochir 92:106-117, 1988

78. Schut L, Bruce DA, Sutton LN: The management of the child with lipomyelomeningocele. Clin Neurosurg 30:464-476, 1983

79. Schwartz JF, O’Brien MS, Hoffman JC Jr: Hereditary spinal arachnoid cysts, distichiasis, and lymphedema. Ann Neurol 7: 340-343, 1980

.80. Shulman L, Bale P, de Silva M: Sacral chondromyxoid fibroma. Pediatr Radiol 15:138-140, 1985

81. Smith J, Wixon D, Watson RC: Giant-cell tumor of the sacrum. Clinical and radiologic features in 13 patients. J Can Assoc Radiol 30:34-39, 1979
82. Sundaresan N, Galicich JH, Chu FC, et al: Spinal chordomas. J Neurosurg 50:312-319, 1979

83. Tarlov I: Perineural cysts of the spinal nerve roots. Arch Neurol Psychiatry 40:1067-1074, 1938

84. Theodorou DJ, Theodorou SJ, Sartoris DJ, et al: Delayed diagnosis of primary non-Hodgkin's lymphoma of the sacrum. Clin Imaging 24:169-173, 2000

85. Thomas M, Halaby FA, Hirschauer JS: Hereditary occurrence of anterior sacral meningocele: report of ten cases. Spine 12: 351-354, 1987

86. Turcotte RE, Sim FH, Unni KK: Giant cell tumor of the sacrum. Clin Orthop 291:215-221, 1993

87. Turner ML, Mulhern CB, Dalinka MK: Lesions of the sacrum. Differential diagnosis and radiological evaluation. JAMA 245: 275-277, 1981

88. Uchiyama M, Iwafuchi M, Naitoh $M$, et al: Sacrococcygeal teratoma: a series of 19 cases with long-term follow-up. Eur J Pediatr Surg 9:158-162, 1999

89. Verhagen WI, Bartels RH, Schaafsma HE, et al: A giant cell tumor of the sacrum or a soft tissue giant cell tumor? A case report. Spine 23:1609-1611, 1998

90. Villarejo F, Scavone C, Blazquez MG, et al: Anterior sacral meningocele: review of the literature. Surg Neurol 19:57-71, 1983

91. Wakhlu A, Misra S, Tandon RK, et al: Sacrococcygeal teratoma. Pediatr Surg Int 18:384-387, 2002

92. Warwick R, Williams P: Gray's Anatomy. Philadelphia: WB Saunders, 1975, pp 1030-1083

93. Whittaker LD, Pemberton JJ: Tumors ventral to the sacrum. Ann Surg 107:96-106, 1938

94. Wilder DG, Pope MH, Frymoyer JW: The functional topography of the sacroiliac joint. Spine 5:575-579, 1980

95. Willis RA: The Borderland of Embryology and Pathology. London: Butterworth, 1962, p 442

96. Wilson SAK: Neurology. London: Edward Arnold, 1940, Vol 2, pp 1285-1321

97. Wood JB, Wolpert SM: Lumbosacral meningioma. AJNR 6: $450-451,1985$

98. Xu WP, Song XW, Yue SY, et al: Primary sacral tumors and their surgical treatment. A report of 87 cases. Chin Med J 103: 879-884, 1990

99. Yokoyama R, Beppu Y, Tobisu Ki K, et al: A multidisciplinary approach to the treatment of malignant pelvic bone tumors: results with eight consectuive patients. J Orthop Sci 5: 449-456, 2000

100. Yonemoto T, Tatezaki S, Takenouchi T, et al: The surgical management of sacrococcygeal chordoma. Cancer 85: 878-883, 1999

101. York JE, Kaczaraj A, Abi-Said D, et al: Sacral chordoma: 40year experience at a major cancer center. Neurosurgery 44: 74-80, 1999

Manuscript received June 13, 2003.

Accepted in final form July 10, 2003.

Address reprint requests to: Michael Payer, M.D., Department of Neurosurgery, University Hopital of Geneva, Rue Micheli-du-Crest 24, 1211 Geneva 14, Switzerland. email: mpayer@hotmail.com. 